\title{
Deleterious GEN1 Gene Mutation
}

National Cancer Institute

\section{Source}

National Cancer Institute. Deleterious GEN1 Gene Mutation. NCI Thesaurus. Code

C156010.

A change in the nucleotide sequence of the GEN1 gene that is associated with increased risk of disease. 